\title{
HEREDITY IN EXOPHTHALMIC GOITER
}

\author{
WITH A REPORT OF TWO JUVENILE CASES * \\ HYMAN CLIMENKO, M.D. \\ NEW YORK
}

In his excellent work on heredity, Dejerine ${ }^{1}$ pointed out the fact that exophthalmic goiter occurs in neuropathic families. He looks on exophthalmic goiter as a form of an hereditary neurosis. Long before Dejerine, Rendu ${ }^{2}$ wrote that persons with this disease had among their ancestors, aliens, epileptics and general paretics. Rendu claimed that there must be a certain relation among all these diseases. Since then Gauthier $^{3}$ has shown the important role played by the thyroid gland in Basedow's disease. Several writers on the subject have attempted to show that there is a direct heredity in exophthalmic goiter. Pende states that primary exophthalmic goiter is always associated with a constitutional hereditary state of irritability and instability of the thyroid, or the regulating nervous system of the thyroid secretion. Pende bases his statements particularly on the reported cases of hereditary exophthalmic goiter. It must, however, be admitted that a fairly careful search of the literature on the subject fails to show an abundance of direct heredity in this disease. Frey ${ }^{5}$ reports a family of four, a father, aged 46, two daughters and one son, all suffering from exophthalmic goiter. Schultheiss ${ }^{6}$ quotes a number of instances from the literature and reports on a family, several members of which suffered from exophthalmic goiter, as well as from diabetes and epilepsy. LeopoldLevi ${ }^{7}$ in discussing the subject points out the rôle of the thyroid instability. Carder in discussing Levi's cases states that the mendelian law of heredity may be applied to exophthalmic goiter disease. Baillich ${ }^{8}$ reports a case of a girl, aged $61 / 2$ years, suffering from exophthalmos;

* Read before Neurological Section, Academy of Medicine, November, 1919.

1. Dejerine: L'heredite, dans les maladies des systeme nervaux, These d'agrey 1886 , p. 157.

2. Rendu: Quoted from E. S. Schulmann: Le goitre exophthalmique syphilitique, These Paris, 1918.

3. Gauthier, de Charolles: Quoted from Longuez Lermagez: Rev. neurol. 26:20, 1919.

4. Pende, N.: Endocrinologia, Milan, 1916, p. 782.

5. Frey, E.: Jahresbericht Neurologie und Psychiatrie 13:753, 1909.

6. Schultheiss, E.: Ueber Erblichkeit Morbus Basedow, Inaugural Dissertation, Jena, 1909; Ztschr. f. Neurol. und Psychiat. 13:750, 1909.

7. Leopold-Levi: Familles thyroid et dysendorm, Gaz. d. hôp. 86:381, 1913.

8. Baillich, G.: Goitre exophthalmique chez une fillette des sept ans heredite similaire, Bull. et mém. Soc. méd. đ. hôp., de Par. 30:708, 1914. 
her father suffered from exophthalmic goiter, her paternal grandmother had a goiter and cardiac trouble, and her mother was extremely nervous. This author believes the disease is transmitted through females. Chapin ${ }^{9}$ discusses the subject of transmission; contrary to the established belief this author proves that women suffering from exophthalmic goiter are prone to great fecundity. His statistics on forty-four women gave to each an average of 4.3 children while that of the normal is 2.5. Many of these women were below 30 years of age. Pregnancy is not affected by exophthalmic goiter and miscarriages are rare. Chapin further shows that the mortality of these children is rather high and that heredity presents itself in similar conditions and other nervous heredity.

Dubrenil-Chambarde1 ${ }^{10}$ also reports a high mortality in infants of mothers suffering from exophthalmic goiter. He further reports a family in which an hysterical mother gave birth to ten children, eight of whom suffered from Basedow's disease. Cases of similar and dissimilar heredity are also cited by Bayloe. ${ }^{11}$ Gauches and Salin ${ }^{12}$ report a case where hereditary syphilis showed itself in the form of polyglandular hyperthyroidism. Schulmann ${ }^{13}$ goes rather more deeply into the subject. After reviewing the literature and citing his own cases, Schulmann comes to the conclusion that hereditary syphilis plays an important part in disturbance of thyroid secretion, and in certain cases a more or less typical form of exophthalmic goiter may result.

Lonques and Lermoyez ${ }^{14}$ report a family with seven cases of exophthalmic goiter. Some further reference to the literature may be found in that article.

\section{REPORT OF CASES}

Case 1. History.-M. B. (Fig. 1), aged 10, came to the Mount Sinai dispensary in September, 1919, with the complaint of swelling in the neck of three months' duration and "nervous spells." Physical examination showed that the child had a pulse of 156; blood pressure-systolic, 125; and diastolic, 85; marked exophthalmos and a marked Möbius' sign. There was a fine tremor of both hands; the face was flushed; there was considerable emaciation; the pupils were markedly dilated and the boy was in a state of apprehension and excitement. There was a marked increase in cardiac dullness to the left, derma-

9. Chapin, A.: De la descendance des Basedowiennes, These Paris, 1910.

10. Dubrenil-Chambardel: Un cas des Basedow hereditaire avec scoliose hereditaire. Province méd. 1907, p. 262.

11. Bayloe: Arch. Med. Tolouse 1896, p. 30.

12. Gaucher et Salin: Insuffisance ovarienne et syndrome des Basedow fruste? Une heredo-syphilitique, Bull. Soc. franç. de dermat. et syph. 23:62, 1912.

13. Schulmann, E. S.: Le tique goitre exophthalmique syphilitique, These Paris, 1918.

14. Lonquez et Lermoyez: Rev. Neurol. 26:20, 1919. 
graphia was present and all the reflexes were exaggerated. Urine was negative; hemoglobin, 70 per cent.; red blood cells 4,024,000; white blood cells 7,200; polynuclears, 62 per cent.: small mononuclears, 29 per cent.; large mononuclears, 7 per cent.; and eosinophils, 1 per cent. Roentgenographic examination the next day showed marked enlargement of the thoracic aorta together with an exaggerated cardiac action. There was an indistinct shadow in the anterior mediastinum which surmounted the aorta and was somewhat suggestive of an enlarged thymus.

While examining the boy, it was noticed that his mother (Fig. 2) who accompanied him presented a typical picture of Basedow's disease, and inquiry elicited the following data.

Case 2.-History-Mrs. B. C. (Fig. 2), the mother of Case 1, is 29 years of age. Her family history shows that her father died from diabetes and her mother suffered in earlier life from attacks of cardiac palpitation, had an enlarged thyroid and had lost considerable weight; but as she grew older her
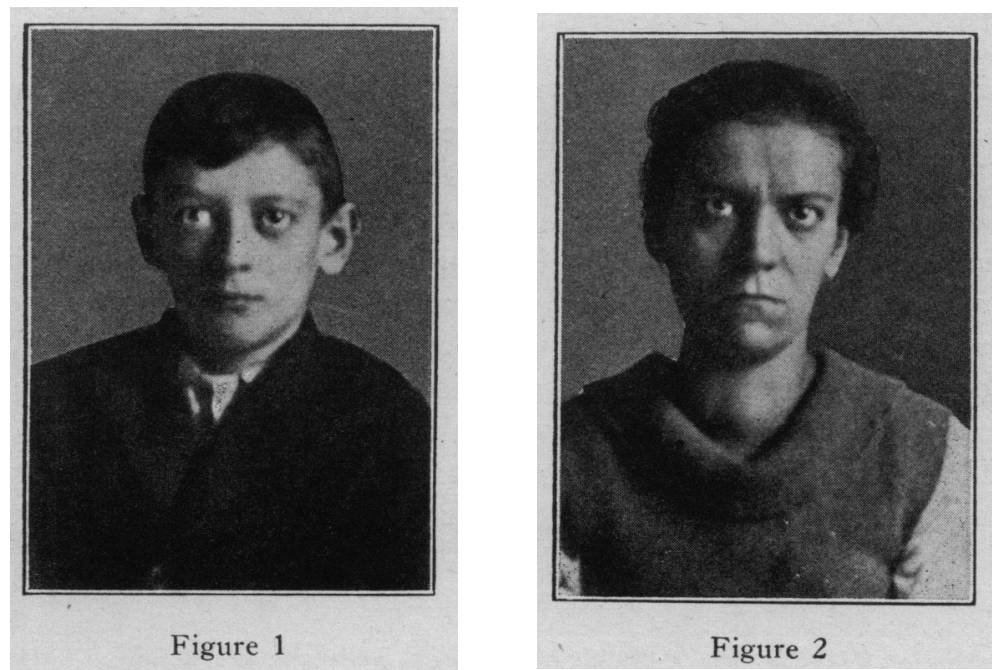

Fig. 1.-Exophthalmic goiter in a boy aged 10.

Fig. 2 (Case 2).-Nother of patient in Case 1, suffering from exophthalmic goiter.

symptoms improved and the swelling in the neck diminished. One sister of the patient underwent operation for exophthalmic goiter at the Mount Sinai Hospital, and another sister is also suffering from a goiter. Mrs. B. C. has had three children and no miscarriages. Only one child is healthy, the third child, a little child aged 6 , is suffering from an enlarged thyroid gland. This case will be reported below.

Examination.-The patient stated that she suffered from frequent cardiac palpitation similar to that of her mother, profuse perspiration, attacks of diarrhea, restlessness and insomnia. There was a marked exophthalmos, and a marked Möbius sign. The patient was emaciated, had a fine tremor of the hands and a tremor of the head was distinctly felt when the examiner's hand was placed on top of it. She had a markedly enlarged thyroid particularly of the left lobe, and marked dermographia. The reflexes were lively. The pulse was 140 ; systolic blood pressure, 138; and diastolic, 85 . She had marked 
pyorrhea. The urine was negative; hemoglobin, 60 per cent.; red blood cells, $3,728,000$; white blood cells, 8,000 ; polynuclears, 52 per cent. ; small mononuclears, 37 per cent.; large mononuclears, 10 per cent., and eosinophils, 1 per cent. Roentgenographic examination of the chest showed marked over-activity of the heart with distinct dilatation, hypertrophy of the left ventricle, considerable dilatation of the aorta, but no evidence of an enlarged thymus or substernal thyroid.

At the request of the examiner, the mother of this patient and grandmother of the first patient was brought to the clinic.

CASE 3.-History.-Mrs. M. W., aged 55, a widow, whose father lived to old age, and whose mother was a very stout woman, had three daughters and one niece who suffered from exophthalmic goiter, and one of her sons was insane. Her husband died from diabetes. The patient was well until about fifteen years
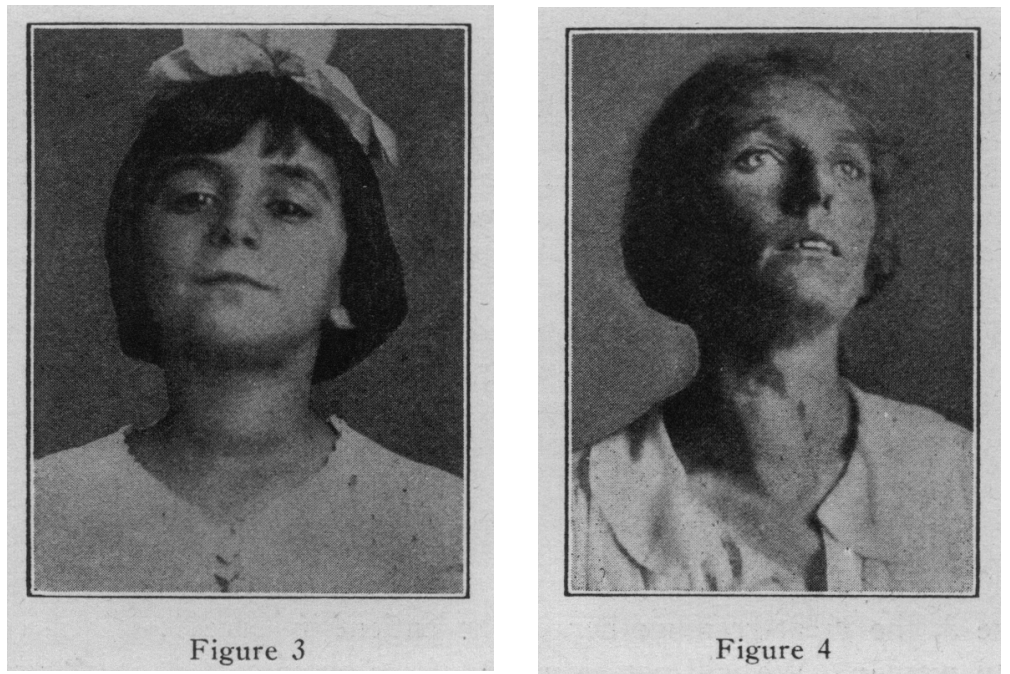

Fig. 3 (Case 4).-Child, aged 6, with exophthalmic goiter.

Fig. 4.-Woman, aged 33, with exophthalmic goiter. Maternal aunt of patients in Cases 1 and 2 .

before she presented herself when she began to suffer from cardiac palpitation and to lose weight rapidly. About one year later she suffered from flushes, and at this time the menopause set in. Her cardiac palpitation continued until about two years ago. At the time of the onset of the thyroid symptoms the gland began to swell, but later on this subsided. After an intra-abdominal operation three years ago, the thyroid symptoms apparently disappeared. At presentation the patient complained of general weakness and rapid exhaustion.

Examination.-This showed a woman who looked much older than the age stated. The pulse was 100 ; systolic blood pressure, 120 ; diastolic, 80 . There was no von Graefe but a distinct Möbius sign is present. There was general emaciation. The reflexes were lively. Blood examination showed: hemoglobin, 65 per cent.; red blood cells, 3,500,000; white blood cells, 8,000 ; polynuclears, 60 per cent.; small mononuclears, 25 per cent. ; large mononuclears, 12 per cent. ; eosinophils, 3 per cent. 
CASE 4.-History.-(Fig. 3). The patient, aged 6, the daughter of the patient described in Case 2, and granddaughter of the patient described in Case 3 , was brought to the clinic by request. Her mother stated that nothing abnormal except the enlargement in the neck could be seen in the child. Examination revealed a very large thyroid, and a von Graefe sign, but no other ocular symptoms. Her pulse was 100 , and she had mild anemia. The urine was negative. A roentgenogram of this patient was not secured.

CASE 5.-History.-B. B. (Fig. 4), the daughter of the patient in Case 3 and sister of the patient in Case 2, aged 33, married, has two healthy children, and gives the same family history as the patient in Case 2. The patient states that she suffers a good deal from painful menstruation, but the periods are regular and normal in quantity. At about the age of 25 she began to notice the enlargement of the thyroid gland, and at the same time the hyperthyroid symptoms began to appear. At the time of presentation she showed a distinct von Graefe sign, a distinct Möbius sign, a general enlargement of the thyroid gland, the right lobe being somewhat larger than the left; she had a fine tremor of the hands; a distinct bruit was heard at the neck; the pulse was 130; the heart was enlarged; the systolic blood pressure was 128; diastolic, 70. The urine was negative; the blood count was not made. Roentgenographic examination showed enlargement of the left ventricle. During the examination the patient was in a state of marked perspiration, and showed marked dermographia.

The daughter of Case 3, who underwent operation for enlarged thyroid, was seen by the examiner, but unfortunately complete examination could not be made. It was, however, learned that she had been gradually improving since the operation, though at times she still suffered from cardiac palpitation.

\section{ANALYSIS OF CASES}

On analyzing our cases, we see that the mother of the patient in Case 3 , the great-grandmother of the patient in Case 1, was a very stout woman. We will not be wrong if we presume that in all probability that woman suffered from a hypothyroid condition. Nature, in order to compensate this condition, gave to the patient in Case 3 the hypersensitive gland which began manifesting undue secretion at middle age. This woman in turn gave birth to children with distinct hyperthyroidal signs which assumed a pathologic aspect in the form of exophthalmic goiter. Here a process of degeneration took place. Nature was apparently making an attempt to eliminate this family. Members of the third generation began to develop symptoms of the disease at the age of 27 ; in the fourth generation the symptoms began to present themselves in a girl of 6 and in a boy of 10 . A natural process of extermination is apparently taking place.

Apparently another factor besides the thyroidal instability is added to the situation of this family, and that is the diabetes in the grandfather of the patient in Case 1. Whether it is due to this factor, or to the instability of the thyroid itself, the fourth generation can no longer 
procreate, in spite of the fact that the husband of the patient in Case 2, the father of the patients in Cases 1 and 4, is a perfectly healthy man of athletic build and even temperament. Consanguinity in this family could not be detected. A Wassermann test was made in all except Case 4, and every reaction was negative; syphilis, therefore, may be excluded. The transmission was a direct one and along the female line. It may also be emphasized that the occurrence of Basedow's symptoms in a boy, aged 10 , and in a girl, aged 6 , is in itself an extremely rare condition, well worth reporting.

69 East Ninetieth Street. 